\title{
Primary hypothyroidism masquerading pituitary macroadenoma
}

\author{
Amit Agrawal ${ }^{1}$, Amareesh P. Reddy $^{2}$, G. Malleswara Rao ${ }^{3}$, \\ Umamaheswara Reddy V. ${ }^{4}$ \\ ${ }^{1}$ Professor of Neurosurgery, Department of Neurosurgery, Narayna Medical College Hospital, \\ Chinthareddypalem, Nellore, Andhra Pradesh (India) \\ ${ }^{2}$ Assistant Professor of Endocrinology, Department of Endocrinology, Narayna Medical College \\ Hospital, Chinthareddypalem, Nellore, Andhra Pradesh (India) \\ 3Professor of Neurosurgery, Department of Neurosurgery, Narayna Medical College Hospital, \\ Chinthareddypalem, Nellore, Andhra Pradesh (India) \\ ${ }^{4}$ Assistant Professor of Radiology, Department of Radiology, Narayana Medical College Hospital, \\ Chinthareddypalem, Nellore, Andhra Pradesh (India)
}

\begin{abstract}
Diffuse and reactive pituitary gland enlargement secondary to primary hypothyroidism is an uncommon occurrence and that can masquerade many pituitary disorders. In present article, we report a case of 19 year female severe hypothyroidism presenting with diffuse enlargement of pituitary gland and hyperprolactinemia and review the clinical importance of this entity. Knowledge of this entity is very important to avoid unnecessary surgery and irreversible complications in this sub-group of patients.

Key words: Pituitary hyperplasia, primary hypothyroidism, pituitary hyperplasia.
\end{abstract}

\section{Introduction}

Diffuse and reactive pituitary gland enlargement secondary to primary hypothyroidism is an uncommon occurrence and that can masquerade many pituitary disorders. (1-8) In present article, we report a case of severe hypothyroidism presenting with diffuse enlargement of pituitary gland and hyperprolactinemia.

\section{Case report}

A 19 year female presented with headache of one year duration and one episode of seizures. There was history of galactorrhoea. There was no history of loss of appetite and cold intolerance. She had easy fatigability and no visual symptoms. Her general and systemic examination was unremarkable. Higher mental functions and cranial nerves were normal. Motor and sensory examination was normal. Deep tendon reflexes were sluggish. Routine blood investigations were within normal range, except low level of hemoglobin (9.1 gm / dL). Hormonal profile revealed raised thyrotropin stimulating hormone (TSH) 
(>100 microlU/dL, range 0.34-5.6) and low T4 (0.10 microgram/mL, range 0.61-1.12). Prolactin was $200 \mathrm{IU} / \mathrm{dL}$. Magnetic resonance imaging (MRI) of the brain showed a large diffuse sellar mass lesion, hypointense on T1W images and uniformly enhancing after contrast administration (Figure 1 and 2). Based on clinical features, investigation reports (increased TSH and prolactin secretion) and imaging findings a diagnosis of diffuse pituitary hyperplasia secondary to primary hypothyroidism was made. The patient was started on 100 microgram thyroxine.

\section{Discussion}

Pituitary hyperplasia is a process and ranges from the slight increase in the number of normal cells without much change in the tissue architecture to massive enlargement of the gland with significant alteration in both tissue architecture and morphology. (9) Thyrotroph hyperplasia is the most common cause of pituitary enlargement in the context of untreated primary hypothyroidism. $(2,10)$ The incidence of pituitary hyperplasia in hypothyroidism ranges from $25 \%$ to $81 \%$ (11) and the incidence is high if the TSH levels are $>50 \mathrm{microIU} / \mathrm{mL}$. (12) It has been suggested that the primary uncontrolled hypothyroidism can be a precursor to pituitary hyperplasia. (2) Low thyroxine levels in these patients results in the loss of negative control on hypothalamo-pituiatry-thyroid axis resulting in the increase of thyrotroph releasing hormone (TRH) from hypothalamus which increases the thyroid stimulating hormone (TSH) from pituitary in an attempt to maintain the normal thyroxine levels $(3,7,13-16)$

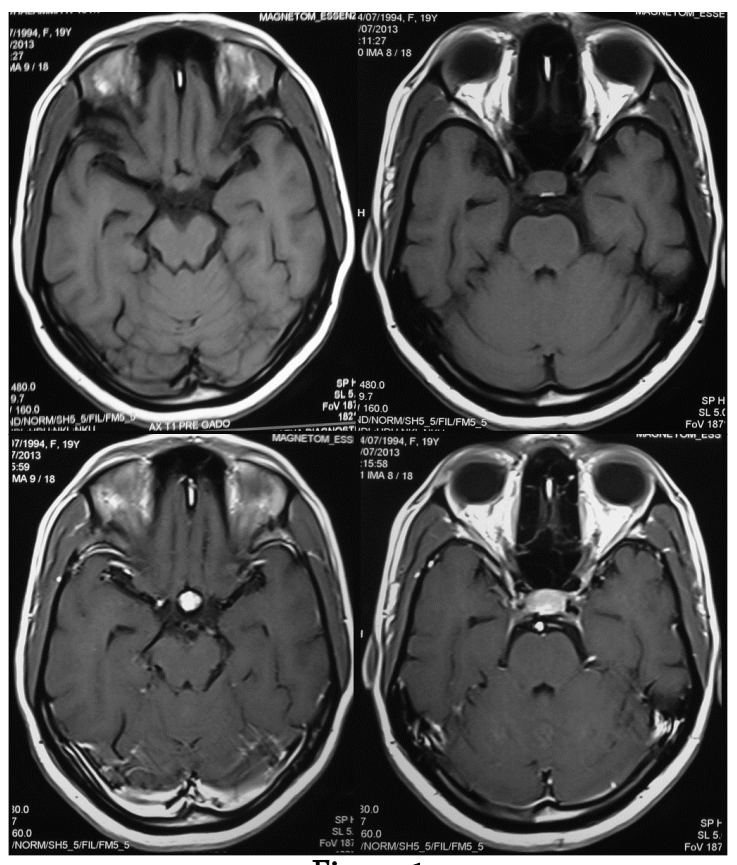

Figure 1

MRI brain axial images showing diffuse enlargement of the pituitary gland, it was hypointense on T1W images and diffusely enhancing after contrast administration

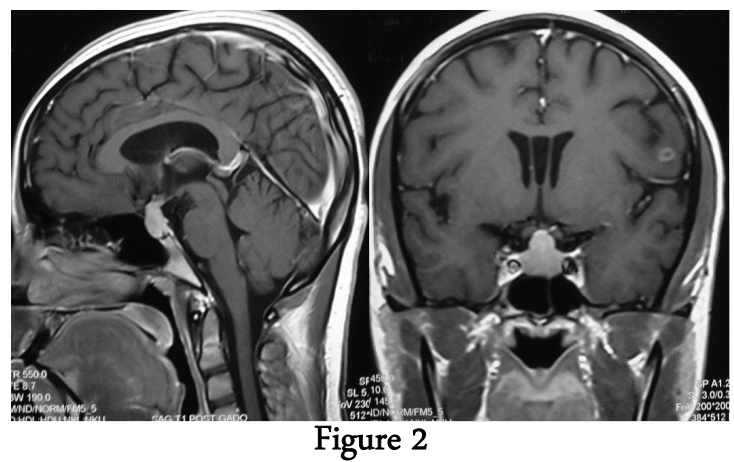

MRI brain sagittal and coronal post-contrast images showing diffusely enhancement of pituitary gland 
As was seen in present case, TRH also exerts a weak stimulatory effect on lactotroph cells resulting in mild to moderate hyperprolactinemia is expected. (13) Because TRH also has a weak stimulatory effect on lactotroph cells, mild to moderate hyperprolactinemia may also occur in about three-quarters of patients. (11) Clinically the patients with pituitary hyperplasia can present with headache, visual symptoms and features of hypothyroidism. $(1,3,7,14)$ It is important to understand that the headache may be due to hypothyroidism, although the exact underlying mechanism is not clear. (7) In many cases pituitary hyperplasias may be clinically silent and focal pituitary hyperplasia can be an incidental finding at autopsy. 9 The diagnosis of pituitary hyperplasia can be difficult and it needs a high degree of clinical suspicion. (1-4, 6-8, 11, 12, 14, 15, 17) Radiological investigations i.e. CT and MRI with contrast administration will show the enlargement of pituitary gland. MRI is superior to CT scan and a follow up imaging will further help to monitor the size of the gland. $(4,6,18-22)$ Detail thyroid functions are the mainstay of diagnosis as it will show decrease in the levels of serum T3 and T4 but greatly elevated serum TSH levels. $(2,3,6)$ One the diagnosis of pituitary hyperplasia secondary to primary hypothyroidism is suspected the patients can be managed with adequate hormone replacement with L-thyroxine (25 to $300 \mathrm{mcg} /$ day) and in most of the cases this will result in relief of symptoms and regression of pituitary hyperplasia within a few months. (1-4, 6-8, $11,12,14,15,17)$ In a selected group of patients where there is compression of the optic chiasm, does not respond to, or worsens under, thyroid hormone replacement or the diagnosis is in doubt surgery may be considered as an option. (23) Although imaging findings will not distinguish between TSH-producing macroadenoma and hyperplasia of pituitary gland, only the follow up imaging and response to replacement therapy will support the diagnosis. (24)

\section{Conclusion}

In summary, diffuse pituitary enlargement can be a manifestation of severe primary hypothyroidism and interpretation of a pituitary mass without an endocrine investigation can lead to unnecessary surgery $(4,5,22,25,26)$. A knowledge of this entity is very important to avoid unnecessary surgery and irreversible complications in this sub-group of patients.

Address for correspondence Dr Amit Agrawal

Professor of Neurosurgery

Department of Neurosurgery

Narayna Medical College Hospital

Chinthareddypalem

Nellore-524003

Andhra Pradesh (India)

Email:dramitagrawal@gmail.com dramit_in@yahoo.com

Mobile: $+91-8096410032$ 


\section{References}

1. Nicholas WC, Russell WF. Primary hypothyroidism presenting as a pituitary mass. Journal of the Mississippi State Medical Association 2000;41:511-514.

2. Joshi AS, Woolf PD. Pituitary hyperplasia secondary to primary hypothyroidism: a case report and review of the literature. Pituitary 2005;8:99-103.

3. Agrawal A, Diwan SK. Pituitary hyperplasia resulting from primary hypothyroidism. Asian journal of neurosurgery 2011;6:99-100.

4. Xu A-J, Li T. [Pituitary hyperplasia secondary to primary hypothyroidism in children: report of 8 cases]. Zhongguo dang dai er ke za zhi $=$ Chinese journal of contemporary pediatrics 2010;12:17-20.

5. Al-Gahtany M, Horvath E, Kovacs K. Pituitary hyperplasia. HORMONES-ATHENS- 2003;2:149-158.

6. Passeri E, Tufano A, Locatelli M, Lania AG, Ambrosi B, Corbetta S. Large pituitary hyperplasia in severe primary hypothyroidism. The Journal of clinical endocrinology and metabolism 2011;96:22-23.

7. Franceschi R, Rozzanigo U, Failo R, Bellizzi M, Di Palma A. Pituitary hyperplasia secondary to acquired hypothyroidism: case report. Italian journal of pediatrics 2011;37:15.

8. Kunjumohamed F. Pituitary hyperplasia and hyperprolactinemia secondary to severe hypothyroidism. Indian Journal of Medical Specialities 2013;4.

9. Horvath E, Kovacs K, Scheithauer BW. Pituitary hyperplasia. Pituitary 1999;1:169-179.

10.Smallridge RC. Thyrotropin-secreting pituitary tumors. Endocrinology and metabolism clinics of North America 1987;16:765-792.

11.Beck-Peccoz P, Brucker-Davis F, Persani L, Smallridge RC, Weintraub BD. Thyrotropin-secreting pituitary tumors. Endocrine reviews 1996;17:610-638.

12.Khawaja NM, Taher BM, Barham ME, et al. Pituitary enlargement in patients with primary hypothyroidism. Endocrine practice : official journal of the American College of Endocrinology and the American Association of Clinical Endocrinologists 2006;12:29-34.

13.Yen PM. Physiological and molecular basis of thyroid hormone action. Physiological reviews 2001;81:10971142.

14.Betônico CCR, Rodrigues R, Mendonça SCL, Jorge PT. [Primary hypothyroidism mimicking pituitary macroadenoma]. Arquivos brasileiros de endocrinologia e metabologia 2004;48:423-426.

15.Young M, Kattner K, Gupta K. Pituitary hyperplasia resulting from primary hypothyroidism mimicking macroadenomas. British journal of neurosurgery 1999;13:138-142.

16.Koller KJ, Wolff RS, Warden MK, Zoeller RT. Thyroid hormones regulate levels of thyrotropinreleasing-hormone mRNA in the paraventricular nucleus. Proceedings of the National Academy of Sciences of the United States of America 1987;84:73297333.

17.Ehirim PU, Kerr DS, Cohen AR. Primary hypothyroidism mimicking a pituitary macroadenoma. Pediatric neurosurgery 1998;28:195-197.

18.Okuno T, Sudo M, Momoi T, et al. Pituitary hyperplasia due to hypothyroidism. Journal of computer assisted tomography 1980;4:600-602.

19.Pita JC, Shafey S, Pina R. Diminution of large pituitary tumor after replacement therapy for primary hypothyroidism. Neurology 1979;29:1169-1172.

20.Sarlis NJ, Brucker-Davis F, Doppman JL, Skarulis MC. MRI-demonstrable regression of a pituitary mass in a case of primary hypothyroidism after a week of acute thyroid hormone therapy. The Journal of clinical endocrinology and metabolism 1997;82:808-811.

21.Wolansky LJ, Leavitt GD, Elias BJ, Lee HJ, Dasmahapatra A, Byrne W. MRI of pituitary hyperplasia in hypothyroidism. Neuroradiology 1996;38:50-52.

22.Shimono T, Hatabu H, Kasagi $K$, et al. Rapid progression of pituitary hyperplasia in humans with primary hypothyroidism: demonstration with MR imaging. Radiology 1999;213:383-388.

23.Simşek E, Simşek T, Savaş-Erdeve S, Erdoğmuş B, Döşoğlu M. Pituitary hyperplasia mimicking pituitary macroadenoma in two adolescent patients with longstanding primary hypothyroidism: case reports and review of literature. The Turkish journal of pediatrics 2009;51:624-630.

24.Eom KS, See-Sung C, Kim JD, Kim JM, Kim TY. Primary hypothyroidism mimicking a pituitary macroadenoma: regression after thyroid hormone replacement therapy. Pediatric radiology 2009;39:164167.

25.Chan AW, MacFarlane IA, Foy PM, Miles JB. Pituitary enlargement and hyperprolactinaemia due to primary hypothyroidism: errors and delays in diagnosis. British journal of neurosurgery 1990;4:107-112.

26.Riedl S, Frisch H. Pituitary hyperplasia in a girl with gonadal dysgenesis and primary hypothyroidism. Hormone research 1997;47:126-130. 